Available online on 15.12.2019 at http://jddtonline.info
Open Access to Pharmaceutical and Medical Research
unrestricted non-commercial use, provided the original work is properly cited

Open $\odot$ Access

Research Article

\title{
A Pharmacovigilance Study on Causality and Severity Assessment of Adverse Drug Reactions in a Teaching Hospital
}

\author{
A. V. Kishore Babu* and A. Srinivasa Rao \\ Department of Pharmacy Practice, Bhaskar Pharmacy College, Hyderabad- 500075, India
}

\begin{abstract}
Objectives: The main purpose of the study is to assess the causality, severity, preventability of ADRs and factors associated with ADRs in chronic disease patients of tertiary care teaching hospital.

Study setting and Design: A Prospective observational longitudinal study was conducted in a tertiary care teaching hospital at Hyderabad, India, for 3 years.

Materials and Methods: Patients of age group > 18 years were included in the study. All the patients were distributed according to their gender, age, number medications used, disease condition, and socioeconomic state. The reported ADRs were analyzed by WHO-UMC causality, Hartwig's Siegel's scale and modified Shumock and Thornton criteria respectively. Statistical analysis used: Descriptive statistical analysis was used.

Results: A total of 691 patients enrolled in the study, in that 391 patients reported with 510 ADRs. Of these $37.0 \%$ are in-patients and $62.9 \%$ are out-patients. Majority of the patients are female category (58.0\%) and 45.8\% of ADRs reported from adults (41-60 years). 65.8\% patients are non-adherent to medication. Life style habits, economic status and education are found to be predictors for ADRs. WHO-UMC scale showed 42.9\% of ADRs probable. Hartwig's and Siegel's severity scales shown $13.1 \%$ ADRs are severe followed by 33.7\% moderate ADRs and 40\% of ADRs were preventable.

Conclusion: Hence our study advises that there is a need of improvement in ADR reporting from health care professionals. This study also suggests further research in India for the improvement of possible intervention strategies to reduce burden and cost of ADR.
\end{abstract}

Keywords: Prospective, ADR reporting, WHO-UMC, Hartwig's Siegel's scale, Shumock and Thornton.

Article Info: Received 13 Sep 2019; Review Completed 08 Nov 2019; Accepted 22 Nov 2019; Available online 15 Dec 2019

\section{Cite this article as:}

Kishore Babu AV, Srinivasa Rao A, A Pharmacovigilance Study on Causality and Severity Assessment of Adverse Drug Reactions in a Teaching Hospital, Journal of Drug Delivery and Therapeutics. 2019; 9(6-s):44-52 http://dx.doi.org/10.22270/jddt.v9i6-s.3746

*Address for Correspondence:

A. V. Kishore Babu, Department of Pharmacy Practice, Bhaskar Pharmacy College, Hyderabad- 500075, India

\section{INTRODUCTION}

According to WHO Pharmacovigilance (PV) is defined as the science and activities relating to the detection assessment, understanding and prevention of adverse effects or any other drug-related problem. WHO established its Programme for International Drug Monitoring in response to the thalidomide disaster detected in 1962.1 ${ }^{2}$ The objective of PvPI is, to monitor ADRs in Indian population, to create awareness amongst health care professionals about the importance of ADR reporting in India, to monitor benefitrisk profile of medicines, generate independent, evidence based recommendations on the safety of medicines, support the $\mathrm{CDSCO}$ for formulating safety related regulatory decisions for medicines, communicate findings with all key stake holders and create a national centre of excellence as par with global drug safety monitoring standards. ${ }^{2}$

It is generally recommended to treat each chronic condition in accordance with disease-specific guidelines. However, most clinical practice guidelines do not modify or discuss the applicability of their recommendations for older patients with multiple diseases and following all guidelines for each and every drug a patient is taking will inevitably lead to polypharmacy. ${ }^{3}$ According to estimates, India has the highest number of adults with diabetes reported at 50.8 millions in 2010 which is expected to rise to 87 million by 2030.4 The prevalence of diabetes has been reported to be rapidly increasing in both rural and urban India. 5 Prescriber's knowledge about pharmacokinetics and pharmacodynamic aspects of medicines and their interaction with normal aging physiology is critical in the management of diabetes mellitus. The knowledge is needed to minimize and even avoid the potentially adverse effects of hypoglycemia and side effects associated with the anti-diabetic drugs. ${ }^{6}$

In the year 2000, it was also found that the world was estimated to have 1 billion people with hypertension and predicted to increase to 1.56 billion by 2025.7 Antihypertensive medications are frequently associated with Adverse Drug Reactions which may limit treatment options and reduce patient compliance, which may hinder Blood 
Pressure control. It was believed that different discontinuation rates for various classes of antihypertensive medications are probably related to their different rates of adverse symptoms. 8 , 9 Treatment of TB requires the use of expensive and toxic anti-tubercular drugs which are given for a longer duration.10,11 The Revised National Tuberculosis Control Program (RNTCP) in India follows the internationally recommended directly observed treatments (DOTS) guidelines for treatment TB from August 2007 onward. 12

The female gender, age (very young and very old), multiple medications and the co-morbid medical conditions, socioeconomic status, educational status and lifestyle habits are considered as the important risk factors for ADRs. ${ }^{13}$

People with diabetes have an increased risk of developing a number of serious health problems. Consistently high blood glucose levels can lead to serious diseases affecting the heart and blood vessels, eyes, kidneys, nerves and teeth. In addition, people with diabetes also have a higher risk of developing infections. ${ }^{14}$ Globally $70 \%$ of diabetic patients are reported to be affected with hypertension and the risk of development of hypertension is twice for diabetic patients as compared to euglycemic subjects. ${ }^{15}$ A high prevalence of DRPs has been observed in T2DM patients. ${ }^{16}$

\section{MATERIALS AND METHODS}

Present study was carried out in Bhaskar Medical College and General Hospital, a tertiary care teaching hospital located in Hyderabad. The study assessed the causality, severity and preventability of ADRs in chronic diseases. Also, the study determined the prevalence of ADRs associated with their educational status, medication adherence, occupation and socioeconomic factors of patients.

Our institute is the recognized ADR monitoring center (AMC) under the "pharmacovigilance program of India." The AMC collects suspected ADR reports from physicians, clinical pharmacy interns, PG medical students as well as nearby teaching hospitals. We transmit reports to the "VigiFlow software "of the WHO for the global monitoring of ADRs provided by Indian Pharmacopoeia Commission, Ghaziabad, India.

\section{Study Design}

Prospective observational longitudinal study with active pharmacovigilance reporting system.

\section{Study Period}

The study was conducted over a period of 3 years from May 2015 to April 2018.

\section{Ethics committee approval}

The study protocol was reviewed and approved by Institutional Human Ethical Committee of Bhaskar Medical College and General Hospital authority prior to the commencement of study.

\section{Study criteria}

\section{Inclusion Criteria}

$>$ Patients of age from 18 years and both genders

$>$ Both inpatients and outpatient
$>$ Patients with any chronic disease and co-morbid medical condition

\section{Exclusion Criteria}

$>$ Children's and pregnant women.

$>$ Patients receiving medicines other than allopathic

$>$ Patients who experienced adverse event to vaccines, blood and /or blood products.

$>$ Adverse event to poisoning/ drug abuse and dependence

\section{Source of Data}

Patient case sheets including clinicians' admission notes, previous discharge summaries available with the patient, reference note from other clinicians and discussion with the patient or their care takers at the time of patients' inclusion were considered as sources of past medical and medication history for both inpatients and outpatients. Clinicians' notes, discussion with the Interns/ medical postgraduate (PG) students were the important sources of information for current medical conditions. Daily medication use during hospital stay was reviewed from nursing notes. Outpatient's drug usage was confirmed from OPD cards, prescription and pharmacy bills or the empty strip of the medication carried by the patient or the care taker.

\section{Assessment of ADR reports}

\section{Organ Systems Affected due to ADRs}

International Statistical Classification of Diseases and Related Health Problems 10th Revision.

\section{Medications Implicated in ADRs}

Drugs that implicated in adverse reaction were coded using the WHO Anatomical,

Therapeutic and Chemical (ATC) classification

\section{Statistical Analysis}

Descriptive statistics were used for data analysis. All values were expressed in percentages and depicted using tables and charts. Data were subdivided based on age, gender, number of drugs used, drugs class, medication adherence, habits, economic status, education and occupation.

\section{RESULTS \& DISCUSSION}

\section{Study Population}

691 patients met the study criteria were included in the study. Of which $37.0 \%(n=256)$ were inpatients and $62.9 \%$ $(n=435)$ were outpatients.

\section{Characteristics of the Study Population}

Out of 691 study patients, $41.9 \% \quad(n=290)$ and $58.0 \%$ $(n=401)$ were male and female respectively. Majority of the patients were in the age group of $40-60$ (45.8\%). $46 \%$ of patients using drugs between $1-2$ drugs. $65.8 \%$ of patients are non adherent to their medication. $34.5 \%$ of patients are both alcoholic and smokers. $50.6 \%$ patients are not educated. $25.4 \%$ of patients are unemployed followed by $20.1 \%$ patients are formers and $34 \%$ of patients are economically lower in class. The demographic details of the study population are given in Table 1. 
Table 1 Demographic details of the study population

\begin{tabular}{|c|c|c|c|c|}
\hline \multicolumn{2}{|l|}{ Characteristics } & $\begin{array}{l}\text { Inpatients (\%) } \\
(\mathrm{n}=256)\end{array}$ & $\begin{array}{l}\text { Outpatients (\%) } \\
(n=435)\end{array}$ & $\begin{array}{l}\text { Total (\%) } \\
(n=691)\end{array}$ \\
\hline \multirow[t]{2}{*}{ Gender } & Male & $107(41.7)$ & $183(42.0)$ & $290(41.9)$ \\
\hline & Female & $149(58.2)$ & $252(57.9)$ & $401(58.0)$ \\
\hline \multirow[t]{3}{*}{ Age } & Young Adult (19-39) & $45(17.5)$ & $44(10.1)$ & $89(12.8)$ \\
\hline & Adult (40-60) & $112(43.7)$ & $205(47.1)$ & $317(45.8)$ \\
\hline & Elderly (>61) & $99(38.6)$ & $186(42.7)$ & $285(41.2)$ \\
\hline \multirow[t]{3}{*}{ No. of Drugs } & $1-2$ & $116(45.3)$ & $202(46.4)$ & $318(46.0)$ \\
\hline & $3-4$ & $89(34.7)$ & $169(38.8)$ & $258(37.3)$ \\
\hline & $\geq 5$ & $51(19.9)$ & $64(14.7)$ & $115(16.6)$ \\
\hline \multirow{2}{*}{$\begin{array}{l}\text { Medication } \\
\text { adherence }\end{array}$} & Adherence & $89(34.7)$ & $147(33.7)$ & $236(34.1)$ \\
\hline & Non & $167(65.2)$ & $288(66.2)$ & $455(65.8)$ \\
\hline \multirow[t]{5}{*}{ Social habits } & Nil & $39(15.2)$ & $80(18.3)$ & $119(17.2)$ \\
\hline & Alcoholic & $57(22.2)$ & $110(25.2)$ & $167(24.1)$ \\
\hline & Smoker & $59(23.0)$ & $93(21.3)$ & $152(21.9)$ \\
\hline & Alcoholic\& Smoker & $99(38.6)$ & $140(32.1)$ & $239(34.5)$ \\
\hline & Abuse & $02(0.7)$ & $12(2.7)$ & $14(2.0)$ \\
\hline \multirow[t]{5}{*}{ Education } & Illiterate & $141(55.0)$ & $209(48.0)$ & $350(50.6)$ \\
\hline & Primary edu & $66(25.7)$ & $102(23.4)$ & $168(24.3)$ \\
\hline & Secondary & $32(12.5)$ & $75(17.2)$ & $107(15.4)$ \\
\hline & Pre university & $13(5.0)$ & $34(7.8)$ & $47(6.8)$ \\
\hline & university & $04(1.5)$ & $15(3.4)$ & $19(2.7)$ \\
\hline \multirow[t]{6}{*}{ Occupation } & Student & $17(6.6)$ & $22(5.0)$ & $39(5.6)$ \\
\hline & Daily worker & $55(21.4)$ & $87(20.0)$ & $142(20.5)$ \\
\hline & Homemaker & $32(12.5)$ & 85 (19.5) & $117(16.9)$ \\
\hline & Agriculture & $62(24.2)$ & $77(3.9)$ & $139(20.1)$ \\
\hline & Salaried/ Busin & $29(11.3)$ & $49(11.2)$ & $78(11.2)$ \\
\hline & Unemployed & $61(23.8)$ & $115(26.4)$ & $176(25.4)$ \\
\hline \multirow[t]{5}{*}{ Socioeconomic } & Upper & $03(1.1)$ & $18(4.1)$ & $21(3.0)$ \\
\hline & Upper middle & $12(4.6)$ & $54(12.4)$ & $66(9.5)$ \\
\hline & Middle Class & $51(19.9)$ & $98(22.5)$ & $149(21.5)$ \\
\hline & Lower Middle & $91(35.5)$ & $129(29.6)$ & $220(31.8)$ \\
\hline & Lower Class & $99(38.6)$ & 1.2) & $(34.0)$ \\
\hline
\end{tabular}

\section{a. Classification of disease condition according to ICD-10 Version: 2016}

Out of 691 patients $41.6 \%$ patients having endocrine, nutritional and metabolic diseases (E00-E90), followed by $18.6 \%$ certain infectious and parasitic diseases (A00-B99). The disease condition details are given in Table 2

Table 2 Classification of disease condition according to ICD-10

\begin{tabular}{|l|l|l|l|l|}
\hline $\begin{array}{l}\text { ICD10 } \\
\text { Chapter }\end{array}$ & \multicolumn{1}{|c|}{ Disease Condition } & $\begin{array}{l}\text { ICD-10 } \\
\text { Code }\end{array}$ & $\begin{array}{l}\text { Total } \\
(\mathbf{n = 6 9 1})\end{array}$ & $\begin{array}{l}\text { Incidence } \\
(\%)\end{array}$ \\
\hline I & Certain infectious and parasitic diseases & (A00-B99) & 129 & 18.6 \\
\hline II & Neoplasams & (C00-D48) & 1 & 0.1 \\
\hline III & $\begin{array}{l}\text { Diseases of the blood and blood-forming organs and certain } \\
\text { disorders involving the immune mechanism }\end{array}$ & (D50-D89) & 18 & 2.6 \\
\hline IV & Endocrine, nutritional and metabolic diseases & (E00-E90) & 288 & 41.6 \\
\hline V & Mental and behavioural disorders & (F00-F99) & 7 & 1.0 \\
\hline VI & Diseases of the nervous system & (G00-G99) & 29 & 4.1 \\
\hline VII & Diseases of the eye and adnexa & (H00-H59) & 2 & 0.2 \\
\hline VIII & Diseases of the ear and mastoid process & (H60-H95) & 2 & 0.2 \\
\hline IX & Diseases of the circulatory system & (I00-I99) & 44 & 6.3 \\
\hline X & Diseases of the respiratory system & (J00-J99) & 22 & 3.1 \\
\hline XI & Diseases of the digestive system & (K00-K93) & 23 & 3.3 \\
\hline XIII & Diseases of the musculoskeletal system and connective tissue & (M00-M99) & 18 & 2.6 \\
\hline XIV & Diseases of the genitourinary system & (N00-N99) & 10 & 1.4 \\
\hline XV & Pregnancy, childbirth and the puerperium & (O00-099) & 15 & 2.1 \\
\hline XVIII & $\begin{array}{l}\text { Symptoms, signs and abnormal clinical and laboratory findings, not } \\
\text { elsewhere classified }\end{array}$ & (R00-R99) & 75 & 10.8 \\
\hline Chapter XIX & Injury, poisoning and certain other consequences of external causes & (S00-T98) & 1 \\
\hline Chapter XXI & Factors influencing health status and contact with health services & (Z00-Z99) & 7 & 0.1 \\
\hline
\end{tabular}




\section{Medication Non-Adherence}

Out of 691 patients $455(65.8 \%)$ are non-adherent to their medication to due to following factors. In that $39.3 \%$ of patients are not following their medications due to drug related factors. The details of medication non-adherence are given in Table 3

Table 3. The reasons for medication non- adherence

\begin{tabular}{|l|l|}
\hline $\begin{array}{c}\text { Factors affecting Medication } \\
\text { adherence }\end{array}$ & $\begin{array}{l}\text { Number (\%) } \\
(\mathbf{n = 4 5 5 )}\end{array}$ \\
\hline Drug Related Factors & $179(39.3)$ \\
\hline Patient Related Factors & $128(28.1)$ \\
\hline Disease Related Factors & $97(21.3)$ \\
\hline Health System Related Factors & $51(11.2)$ \\
\hline
\end{tabular}

Figure 1: Factors affecting medication adherence $(n=455)$

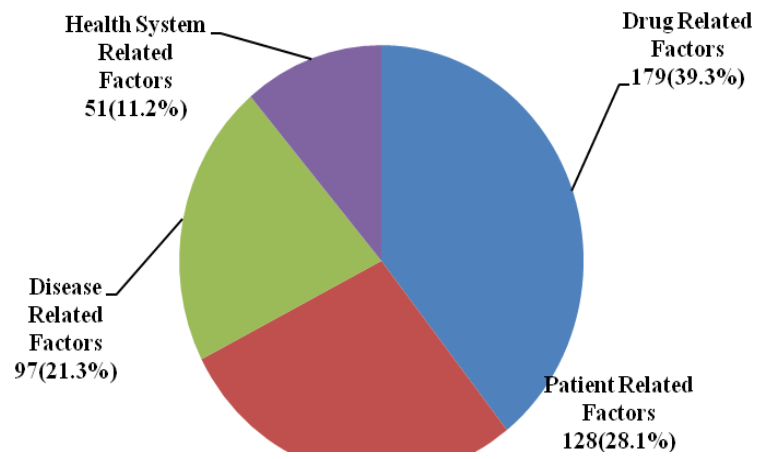

\section{Adverse Drug Reaction}

Out of 691 patients enrolled in the study 391 patients reported with 510 ADRs during the study period. The incidence of ADRs details are given in Table 4

Table 4. Incidence of ADRs based on patient characteristics

\begin{tabular}{|c|c|c|c|c|c|}
\hline Characteristics & $\begin{array}{l}\text { Number } \\
\text { of patients } \\
(n=691)\end{array}$ & $\begin{array}{l}\text { Number of } \\
\text { patients with } \\
\text { ADR }(n=391)\end{array}$ & Incidence & $\begin{array}{l}\text { Number } \\
\text { of ADRs } \\
(n=510)\end{array}$ & $\begin{array}{l}\text { Percentage } \\
\text { of ADRs(\%) }\end{array}$ \\
\hline \multicolumn{6}{|l|}{ Category } \\
\hline Inpatients & 256 & 106 & 41.4 & 143 & 28.0 \\
\hline Out patients & 435 & 285 & 65.5 & 367 & 71.9 \\
\hline \multicolumn{6}{|l|}{ Gender } \\
\hline Male & 290 & 190 & 65.5 & 239 & 46.8 \\
\hline Female & 401 & 201 & 50.1 & 271 & 53.1 \\
\hline \multicolumn{6}{|l|}{ Age ( years) } \\
\hline Young Adults & 89 & 31 & 34.8 & 48 & 9.4 \\
\hline Adults & 317 & 187 & 58.9 & 258 & 50.5 \\
\hline Elderly (>61) & 285 & 173 & 60.7 & 204 & 40.0 \\
\hline \multicolumn{6}{|c|}{ Number of Medications } \\
\hline 1-2 & 318 & 218 & 68.5 & 261 & 51.1 \\
\hline $3-4$ & 258 & 108 & 41.8 & 159 & 31.1 \\
\hline$>5$ & 115 & 65 & 56.5 & 90 & 17.6 \\
\hline \multicolumn{6}{|c|}{ Medication Adherence } \\
\hline Adherence & 236 & 113 & 47.8 & 169 & 33.1 \\
\hline Non Adherence & 455 & 278 & 61.0 & 341 & 66.8 \\
\hline \multicolumn{6}{|c|}{ Disease condition ICD-10 } \\
\hline (A00-B99) & 129 & 107 & 82.9 & 176 & 34.5 \\
\hline (C00-D48) & 1 & 1 & 100 & 1 & 0.1 \\
\hline (D50-D89) & 18 & 9 & 50 & 13 & 2.5 \\
\hline (E00-E90) & 288 & 145 & 50.3 & 152 & 29.8 \\
\hline (F00-F99) & 7 & 4 & 57.1 & 6 & 1.1 \\
\hline (G00-G99) & 29 & 17 & 58.6 & 24 & 4.7 \\
\hline (H00-H59) & 2 & 1 & 50 & 1 & 0.1 \\
\hline (H60-H95) & 2 & 1 & 50 & 1 & 0.1 \\
\hline$(100-199)$ & 44 & 23 & 52.2 & 26 & 5.0 \\
\hline$(\mathrm{J00}-\mathrm{J99})$ & 22 & 16 & 72.7 & 21 & 4.1 \\
\hline (K00-K93) & 23 & 11 & 47.8 & 13 & 2.5 \\
\hline (M00-M99) & 18 & 6 & 33.3 & 9 & 1.7 \\
\hline (N00-N99) & 10 & 4 & 40 & 7 & 1.3 \\
\hline$(000-099)$ & 15 & 8 & 53.3 & 12 & 2.3 \\
\hline (R00-R99) & 75 & 34 & 45.3 & 42 & 8.2 \\
\hline (S00-T98) & 1 & 1 & 100 & 1 & 0.1 \\
\hline (Z00-Z99) & 7 & 3 & 42.8 & 5 & 0.9 \\
\hline
\end{tabular}




\section{a. Department-wise distribution of ADRs}

Maximum number of ADRs were reported from the department of general medicine (69.5\%),similar with the study done by Rajeshreddy SGSV et al.17 followed by Pulmonology (15.8\%), OBG (5.8\%) and DVL (2.5\%). The department wise details are given in Table 5

Table 5. Department wise distribution of ADRs

\begin{tabular}{|l|l|l|}
\hline Department & No. of ADRS (n=510) & Incidence (\%) \\
\hline General Medicine & 356 & 69.8 \\
\hline Pulmonology & 78 & 15.2 \\
\hline Obstetrics and gynaecology & 30 & 5.8 \\
\hline DVL ( dermatology, vernerology, leprology) & 16 & 3.1 \\
\hline Orthopaedics & 9 & 1.7 \\
\hline Psychiatry & 9 & 1.7 \\
\hline Other* & 12 & 2.3 \\
\hline
\end{tabular}

(* casualty, ENT, neurology \& surgery)

\section{b. Anatomical and Therapeutic Class of medication} implicated in ADRs

Drugs acting on alimentary tract and metabolism accounts for $34.5 \%$ and anti-infective for systemic use reports 33.3\%
ADRs having similar reports from the study done by Patel, et al. ${ }^{18}$ are the most common anatomical class of medication implicated in ADRs. The details of Anatomical and Therapeutic Class of medication implicated in ADRs are given in Table 6

Table 6. Anatomical and Therapeutic Class of medication implicated in ADRs

\begin{tabular}{|c|c|c|}
\hline $\begin{array}{l}\text { Anatomical class [Code] } \\
\text { (Number of ADRs) }\end{array}$ & Therapeutical class [Code] & $\begin{array}{l}\text { Number of } \\
\text { ADRs } \\
n=510(\%)\end{array}$ \\
\hline \multirow{4}{*}{$\begin{array}{l}\text { Alimentary tract and metabolism [A] } \\
\qquad[\mathrm{n}=176(34.5)]\end{array}$} & Drugs for acid related disorders [A02] & 29 \\
\hline & Antiemetics and Antinauseants [A04] & 23 \\
\hline & Drugs used in diabetes [A10] & 90 \\
\hline & Vitamins [A11] & 34 \\
\hline $\begin{array}{l}\text { Blood and blood forming organs [B] } \\
{[\mathrm{n}=5(0.9)]}\end{array}$ & Antithrombotic Agents [B01] & 5 \\
\hline \multirow{5}{*}{$\begin{array}{l}\text { Cardiovascular system }[\mathrm{C}] \\
\qquad[\mathrm{n}=34(6.6)]\end{array}$} & Antihypertensive [C02] & 16 \\
\hline & Diuretics [C03] & 5 \\
\hline & Beta blocking agents [C07] & 3 \\
\hline & Calcium Channel Blockers [C08] & 4 \\
\hline & lipid modifying agents [C10] & 6 \\
\hline \multirow{2}{*}{$\begin{array}{l}\text { Systemic hormonal preparations, } \\
\text { excl. sex hormones and insulins }[\mathrm{H}] \\
{[\mathrm{n}=31(6.0)]}\end{array}$} & Corticosteroids for systemic use [H02] & 27 \\
\hline & Thyroid therapy [H03] & 4 \\
\hline \multirow{3}{*}{$\begin{array}{l}\text { Anti-infective for systemic use [J] } \\
{[n=170(33.3)]}\end{array}$} & Antimycobacterial [J04] & 118 \\
\hline & Antibacterials for systemic use [J01] & 48 \\
\hline & Antivirals For Systemic use [J05 ] & 4 \\
\hline $\begin{array}{c}\text { Musculo-Skeletal system [M] } \\
{[\mathrm{n}=19(3.7)]}\end{array}$ & Antiinflammatory [M01] & 19 \\
\hline \multirow{5}{*}{$\begin{array}{l}\text { Nervous system }[\mathrm{N}] \\
{[\mathrm{n}=55(10.7)]}\end{array}$} & Analgesic [N02] & 30 \\
\hline & Antiepileptics [N03] & 17 \\
\hline & Psycholeptics [N05] & 4 \\
\hline & Other nervous system drugs [N07] & 2 \\
\hline & Antidepressants [N06a ] & 2 \\
\hline \multirow{2}{*}{$\begin{array}{c}\text { Antiparasitic products, } \\
\text { insecticides and repellents [P] } \\
{[\mathrm{n}=11(2.1)]}\end{array}$} & $\begin{array}{l}\text { Ectoparasiticides, incl. Scabicides, insecticides } \\
\text { and repellents [P03] }\end{array}$ & 2 \\
\hline & Antiprotozoals [P01] & 9 \\
\hline $\begin{array}{c}\text { Respiratory System [R] } \\
{[\mathrm{n}=9(1.7)]}\end{array}$ & Drugs for obstructive airway diseases [R03] & 9 \\
\hline
\end{tabular}




\section{c. Organ system affected by ADRs.}

In our study gastrointestinal system accounts for $26.2 \%$ ADRs and Skin disorders accounts for 26\%, having similar reports from the study done by R.J. Lihite et al. and Rehan HS et al. ${ }^{19,} 20$ The details of organ system affected are given in Table 7.

Table 7. Distribution of ADRs based on system organ class affected

\begin{tabular}{|l|l|l|}
\hline System organ class (WHOART SOC code) & $\begin{array}{l}\text { Number of } \\
\text { ADRs (n=510) }\end{array}$ & Incidence (\%) \\
\hline Body as a whole - general disorders (1810) & 59 & 11.5 \\
\hline Cardiovascular disorders (1010) & 7 & 1.3 \\
\hline Central \& peripheral nervous system disorders 0410 & 8.6 \\
\hline Gastro-intestinal system disorders (0600) & 44 & 26.2 \\
\hline Hearing and vestibular disorders 0432 & 134 & 0.1 \\
\hline Heart rate and rhythm disorders 1030 & 01 & 0.7 \\
\hline Liver and biliary system disorders & 4 & 1.9 \\
\hline Metabolic and nutritional disorders 0800 & 10 & 12.1 \\
\hline Musculo-skeletal system disorders 0200 & 62 & 2.3 \\
\hline Platelet, bleeding \& clotting disorders 1230 & 12 & 1.3 \\
\hline Psychiatric disorders 0500 & 07 & 2.3 \\
\hline Red blood cell disorders (1210) & 12 & 0.7 \\
\hline Respiratory system disorders 1100 & 04 & 1.7 \\
\hline Skin and appendages disorders (0100) & 09 & 26.0 \\
\hline Urinary system disorders 1300 & 133 & 1.5 \\
\hline Special senses other, disorders 0433 & 08 & 0.1 \\
\hline Vision disorders 0431 & 01 & 0.1 \\
\hline White cell disorders 1220 & 01 & 0.3 \\
\hline
\end{tabular}

\section{d. Types of medication implicated in ADRs}

Antimicrobial agents accounts for $35.4 \%(n=181)$, which is in accordance with the result of studies done by Murphy B et. al and Lukshmy M Hettihewa et al.21, 22 and antidiabetic drugs accounts for $17.6 \%(n=90)$ followed by analgesic and antiinflammatory drugs $(9.6 \%, n=49)$ of ADRs. The details of types of medication are given in Figure 2.

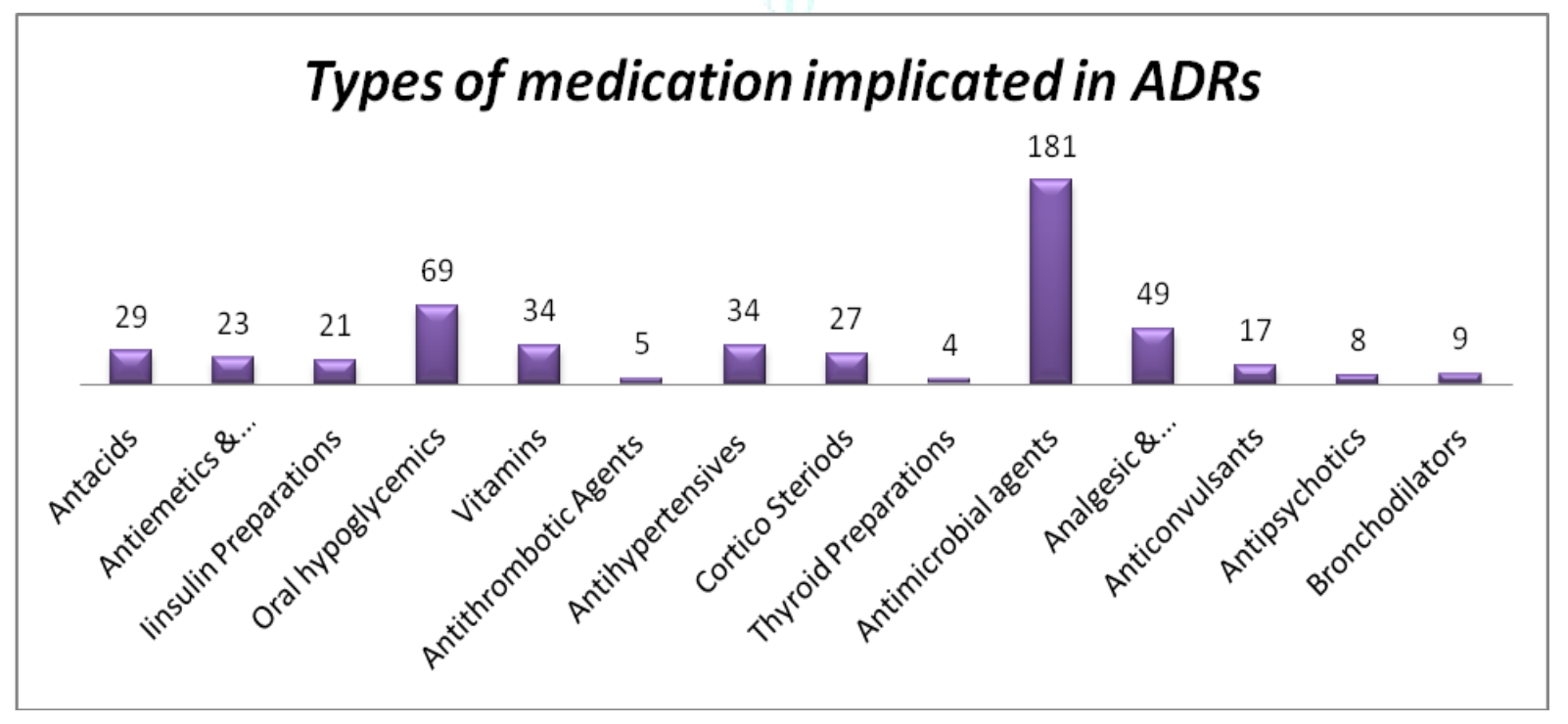

Figure 2: Type of medication implicated in ADRs 


\section{e. Type of Reporters}

All the ADRs reported spontaneously, in that majority of the ADRs (28.8\%) were reported by PG/ Pharm.D Interns, followed by physicians (22.7) and nurses (18.8\%). Highest reporting from Pharm.D interns, because active participation in daily ward rounds and performing bedside patient counselling and patient to patient interaction. Surprisingly patients are also involved in reporting of the ADRs showing that improvement in awareness of drug usage and related problems. The details of reporters are given in Figure 3

\title{
Type of Reporter $\mathrm{n}=\mathbf{5 1 0}$
}

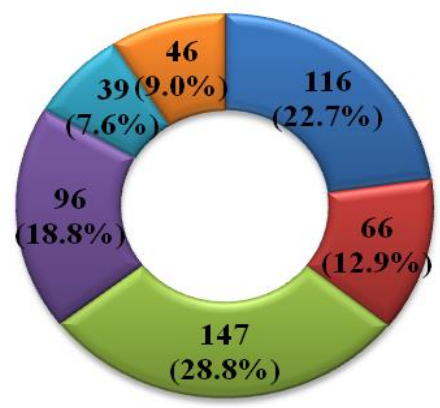

\author{
Q Physician \\ $\square$ Pharmacist \\ $\square$ PG / Interns \\ $\square$ Nurse \\ Patient \\ 四 Other
}

Figure 3. Type of reporters

\section{f. Predictability of the ADRs}

A total of $76.6 \%(n=391)$ of the adverse drug reactions were predictable, related with the study Asawari L Raut et al. ${ }^{23}$ and $23.3 \%(n=119)$ of the adverse drug reactions were not predictable. The details of predictability of the ADRs are given in Figure 4

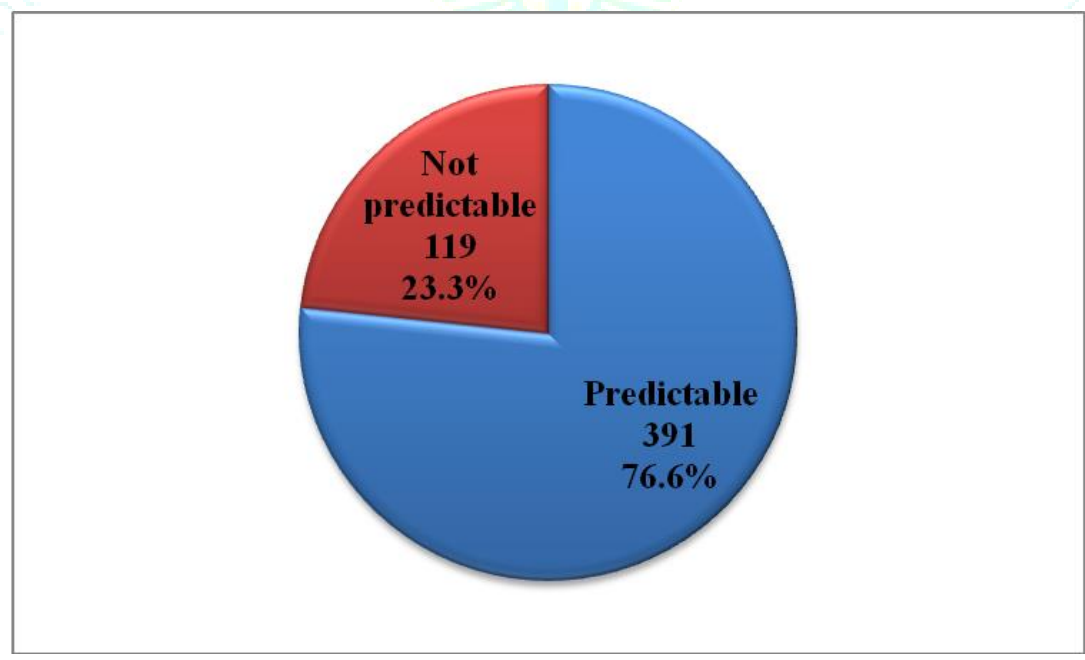

Figure 4. Predictability of the ADRs

Approximately three-fourth of reported ADRs was predictable. This result perhaps may due to the reason that majority of the reactions were exacerbation of pharmacological actions of the drugs that act on various organs and associated receptor site.

\section{g. Causality assessment of reported ADRs}

Majority of the ADRs belonged to 'probable' in their casual relationship, as assessed

by WHO probability Scale [n=219 (42.9\%)], similar with study done by Rajeshreddy SGSV et al. ${ }^{17}$ The causality categories of reported ADRs are presented in Figure .

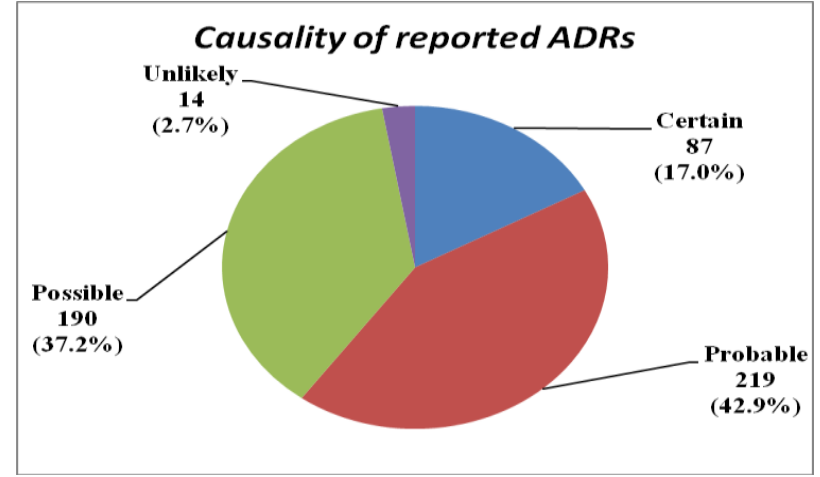

Figure 5. WHO-UMC Causality categories of reported ADRs 
The WHO UMC proposed causality assessment is generally accepted method and most widely used method for causality assessment in clinical practice as they offered a simple methodology. Majority of the ADRs were assigned 'Probable' casual association between the adverse drug event and suspected drug.

\section{h. Severity assessment of ADRs}

Most of the reported ADRs were of 'Mild' in their severity and hence did not require withdrawal of the suspected drug especially when the benefits outweighed the risk. This finding coincide with ponnusankar et al., Dindayal Patidar et al. 24,25 the details of severity of ADRs are given in Figure 6.

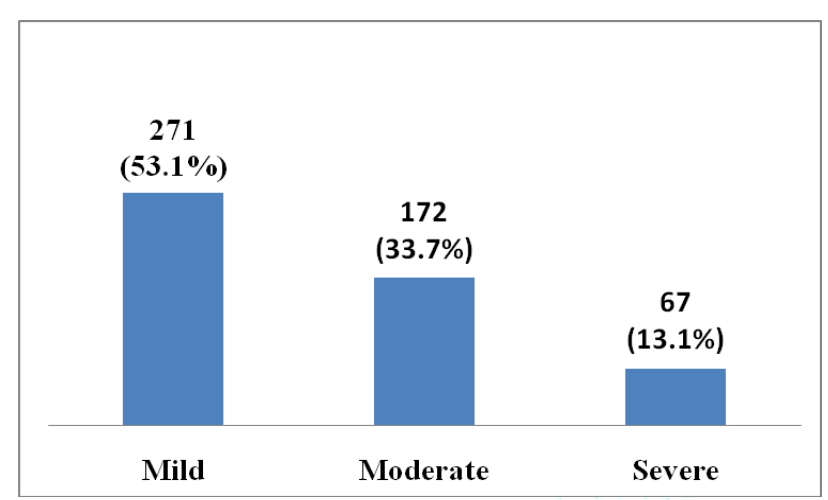

Figure 6. Severity of ADRs

\section{i. Preventability of the ADRs}

Of the 510 reported ADRs, 269 (52.7\%) were classified as probable preventable, which is variance with the study done by ponnusankar et al.24 The details of the preventability of ADRs are presented in Figure 7.

Figure 7. Preventability of ADRs

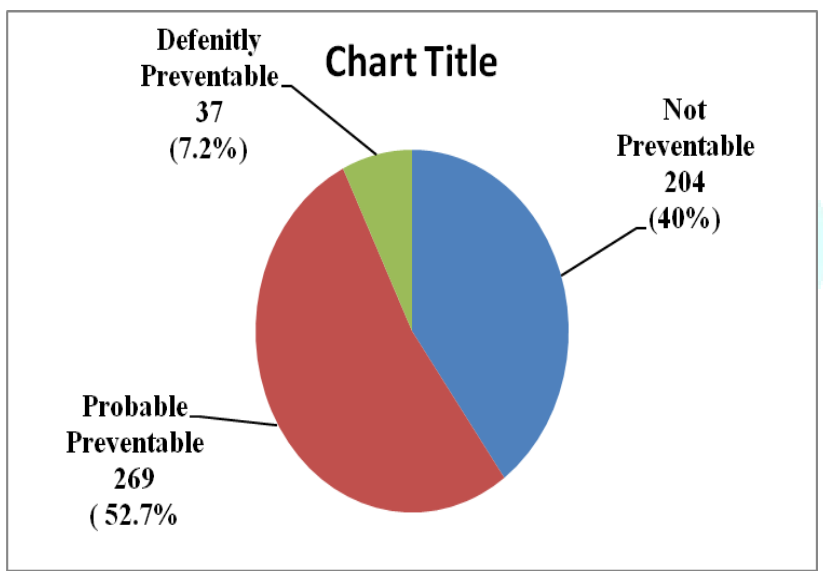

\section{CONCLUSION}

Our findings suggest students' reports were valuable and offered clinically relevant information. ADR monitoring through spontaneous reporting system helps to ensure patient safety through detection of new, serious, and rare drug reactions. Pharm.D interns and PG medical students as a future health-care professional should be exposed to ADR reporting during their clinical teaching posting. The present study relates to ADR profile of tubercular agents, antidiabetic drugs, cardiovascular and antibiotics, it is important to notice the physicians with latest adverse drug reactions of most commonly prescribed medicines in hospitals. Hence effective implementation of pharmacovigilance would result in better strict vigilance use of these drugs and their safety assessment which would ultimately result in better patient care.

\section{ACKNOWLEDGEMENTS}

Authors would like to acknowledge ADR Monitoring Centre, Bhaskar Medical College and Bhaskar General Hospital, Hyderabad, Telangana for their kind support to conduct this study.

\section{REFERENCES}

1. WHO.https://www.who.int/medicines/areas/quality_safety/ safety_efficacy/pharmvigi/en/

2. Pharmacovigilance Programme of India (PvPI) for Assuring Drug Safety. Available from http://cdsco.nic.in/pharmacovigilance_intro.htm

3. Boyd CM, Darer J, Boult C, Fried LP, Boult L, Wu AW. Clinical practice guidelines and quality of care for older patients with multiple comorbid diseases: implications for pay for performance. JAMA. 2005; 294(6):716-24. doi: 10.1001/jama.294.6.716.

4. IDF. Diabetes Atlas. 4th ed. Brussels, Belgium: International Diabetes Federation; 2009.

5. Ramachandran A, Snehalatha C. Current scenario of diabetes in India. J Diabetes. 2009;1(1):18-28.

6. Coren J, Overbeck K, Filipetto F. Evaluating medications and adverse drug reactions in older patients, 2011. Available from: http:// www.cecity.com /aoa/healthwatch/may_11/print2.pdf. [Last cited on 2015 Nov 07].

7. Michel Joffres et al., Hypertension prevalence, awareness, treatment and control in national surveys from England, the USA and Canada, and correlation with stroke and ischaemic heart disease mortality: a cross-sectional study. British Medical Journal 2013; 3: e003423.

8. Degli Esposti E, Sturani A and Di Martino N: Long term persistence with anti-hypertensive drugs in new patients. Journal of Human Hypertension 2002; 16: 439-444.

9. Degli Esposti L, Degli Esposti E and Valpiani G: A retrospective, population- based analysis of persistence with anti-hypertensive drug therapy in primary care practice in Italy. Clinical Therapeutics 2002; 24: 1347-1357.

10. Iseman MD. Treatment of multidrug-resistant tuberculosis. N Engl J Med. 1993; 329:784-91.

11. Drobniewski FA, Balabanova YM. The diagnosis and management of multiple-drug-resistant-tuberculosis at the beginning of the new millenium. Int J Infect Dis. 2002; 6(Suppl 1):S21-31.

12. Shin SS, Pasechnikov AD, Gelmanova IY, Peremitin GG, Strelis AK, Mishustin S, et al. Adverse reactions among patients being treated for MDR-TB in Tomsk, Russia. Int J Tuberc Lung Dis. 2007; 11:1314-20.

13. Bhabhor PH, Patel TK, Vahora R, Patel PB, Desai N. Adverse drug reactions in a tertiary care teaching hospital in India: Analysis of spontaneous reported cases. Int J Basic Clin Pharmacol 2014; 3(6):1078-85.

14. https://www.idf.org/our-activities/careprevention/cardiovascular-disease.html

15. Purohit P: A cross-sectional study of type -2 diabetic females at a higher CVD risk owing to a strong correlation of Systolic hypertension to CVD risk factors. Int J Biol Med Res. 2012; 3:1905-1909.

16. Haugbolle LS, Sorensen EW: Drug-related problems in patients with angina pectoris, type 2 diabetes and asthmainterviewing patients at home. Pharm World Sci 2006, 28(4):239-247.

17. Rajeshreddy SGSV, V., Lokesh V. Patil. Causality assessment and the severity of the adverse drug reactions in tertiary care hospital: a pharmacovigilance study, Int J Basic Clin Pharmacol. 2017; 6(12):2800-2803.

18. Patel PB, Patel TK, Anturlikar S, Khatun S, Bhabhor P, Saurabh MK. Adverse drug reactions reporting by undergraduate medical students in a tertiary care teaching hospital of India: Content and quality analysis in comparison to physician reporting. Perspect Clin Res 2017; 8:137-44. 
19. Ratan J. Lihite, Mangala Lahkar, Sukirti Das, Debeeka Hazarika, Murali Kotni, Mudasir Maqbool, Swapna Phukan. A study on adverse drug reactions in a tertiary care hospital of Northeast India. Alexandria Journal of Medicine. 2017 53, 151-156.

20. Rehan HS, Chopra D, Sah RK, Mishra R. Adverse drug reactions: trends in a tertiary care hospital. Curr Drug Saf 2012; 7:384-8.

21. Murphy BM, Frigo LC. Development, implementation, and results of a successful multidisciplinary adverse drug reaction reporting program in a university teaching hospital, Hosp Pharm. 1993; 28(12):1199-204.

22. Hettihewa LM, Sirisena B. Casualty assessment and the severity of the adverse drug reactions (ADR) actively detected in hospital-in patients in tertiary care hospital Sri Lanka:
Prospective observational survey. Asian Journal of Research in Biological and Pharmaceutical Sciences. 2014; 2(1):1-10.

23. Asawari L Raut, Palak Patel, Chintan Patel and Atmaram Pawar. Preventability, Predictability and Seriousness of Adverse Drug Reactions amongst Medicine Inpatients in a Teaching Hospital: A Prospective Observational Study, ijpcs, Vol. 1 (3) Jul-Sep 2012.

24. S. ponnusankar, $m$. tejaswini and $m$. chaitanya. ADR Assessment Based on Spontaneous Signaling, Indian J Pharm Sci 2015; 77(4):490-493.

25. Dindayal Patidar, Mithun S. Rajput, Nilesh P. Nirmal, Wenny Savitri. Implementation and evaluation of adverse drug reaction monitoring system in a tertiary care teaching hospital in Mumbai, India, Interdiscip Toxicol. 2013; 6(1):4146. 